\title{
坐りに伴うスケトゥダラ肉糊中のタンパク質の 塩溶解性と成分組成の变化
}

\author{
船津保浩, 加藤 登, 新井健一
}

(1994 年 1 月 18 日受付)

\begin{abstract}
Changes in Salt-Solubility and Subunit Components of Myofibrillar Proteins in Salt-Ground Meat from Walleye Pollack Surimi during Setting

Yasuhiro Funatsu, ${ }^{* 1,2}$ Noboru Kato, ${ }^{* 3}$ and Ken-ichi Arai ${ }^{* 1,4}$
\end{abstract}

\begin{abstract}
Frozen surimi was chopped with $2.5 \% \mathrm{NaCl}$ at $\mathrm{pH} 6.9$ and 6.0 . The salt-ground meats were then incubated at $25^{\circ} \mathrm{C}$. During the setting, part of the salt-ground meat was solubilized into $0.80 \mathrm{M} \mathrm{NaCl}$ solution. The content and subunit components of myofibrillar proteins in salt-soluble (S) and insoluble (P) fractions were investigated.

In the early stage of setting, a large amount of myosin heavy chain (HC) and actin containing tropomyosin, together with a small amount of cross-linked myosin $\mathrm{HC}\left(\mathrm{HC}_{n}\right)$ and unidentified components $\left(X_{1}\right.$ and $\left.X_{2}\right)$, constituted the $S$ fraction from meats of both pHs. With the progress of setting, the decrease in salt-soluble protein from the meat of $\mathrm{pH} 6.0$ was rather slower than that of $\mathrm{pH} 6.9$. In addition, all subunit components including the large amount of myosin $\mathrm{HC}$ disappeared from the $\mathrm{S}$ fraction, and a concomitant accumulation of $\mathrm{HC}_{n}$ at $\mathrm{pH} 6.9$ (or $\mathrm{HC}_{n}$ plus $\mathrm{X}_{1}$ at $\mathrm{pH}$ 6.0) together with all other components was observed in the $P$ fraction.

These results indicate that all protein components in the salt-ground meat were complexed to form the salt-insoluble protein fraction in the process of setting.
\end{abstract}

キーワード：坐り, 肉糊, 塩溶性タンパク質, 筋原䄉維タンパク質, スケトウダラ, ミオシン重鎖, アクチン

先に著者らは中性および微酸泩下で坐らせた塩ずり肉 （肉糊）をSDS, *5 尿素，およびメルカプトエタノールを 含む溶液（SDS一尿素湜液上略す）に溶解し，可溶化した 筋原瀻維（Mf上略す）タンパク澌の組成を沿倉ら ${ }^{1,2)}$ 提案した方法に従って SDS-ポリアクリルアミト電気泳 動（SDS-PAGEと略す）に供武し，比色定量してきた。” その結果，微酸性下では中性に比へミオシン重鎖（HC と略す）の威少に伴うその多嘗体の生成が起こりにくく なるが，その上さらにミオシン HCとアクチン（Aと略 方）上の間に泳動される未同定の成分（X成分上略す） が生成する分だけミオシン HC多量体の生成量が成り, それが破断强度の減少よよく対応していることを見いだ した。しかし，この方法で定量される成分はそのほとん どがサブユニットに相当し，供試されたタンパク質が高 次構造加ら成っていてもそれを見分けることができな
い。特にゲル化したタンバク質は书をらく Mf タンパク 貿成分放よびそのサブュニット間でポリペプチド鎖内お よび鎖間に非共有結合性の弱い結合を形成して凝集して いるものと推定さ机るが，そ机らの結合はSDS一尿素混 液中で切断されるためその本体を把握することはできな w。

そこで，本研究では中性おょび微酸性下での坐り中の 肉糊の一部をとり出し，高摆度の $\mathrm{NaCl}$ 溶液で溶解し， 塩溶性のタンパク質と不溶性のタンパク質に分けた後 にそれぞれのサブュニット成分の組成と分布を検討 し，ゲル化タンパク質の本体を類推しようと試みた。

\section{実験方法}

試料 スケトウダラ (Walleye pollack) Theragra chalcogramma の冷涷すり身を材料として用いた。このすり身

*1 元北海道大学水産学部生物化学教䇪 (Formerly, Laboratory of Biochemistry, Faculty of Fisheries, Hokkaido University, Minato, Hakodate, Hokkaido 041, Japan).

*2 見所属：富山䝿食品研究所 (Toyama Food Research Institute, Yoshioka, Toyama 939, Japan).

*3 紀文食品(侏) (Kibun Food Institute, Ginza, Chuo, Tokyo 104, Japan).

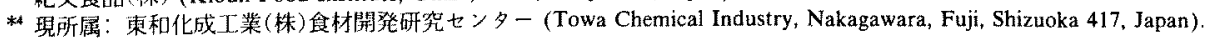

*s 格語 SDS, Sodium Dodecyl Sulfate. 
はショ糖 4\%とンルビトール $4 \%$ を含有し，水分量は $74.1 \%, \mathrm{pH}$ は6.9で,ビウレット法尔によって測定した夕 ソパク質濃度は $181.1 \mathrm{mg} / \mathrm{g}$ (すり身湿重量)であり, 製 造後 $-30^{\circ} \mathrm{C}$ で 2 年間眝蔵したものである。

かまほこゲルの調製 すり身のタンパク質濃度が 130 $\mathrm{mg} / \mathrm{g}$ (湿重量)となるように水と $2.5 \%$ の NaCl（終濃 度）を添加し，スピードカッター（ナショナル MK-K7) を用いて 5 分間 $4{ }^{\circ} \mathrm{C}$ 以下の低温でらいかいし，肉糊を調 製した。肉糊中の気泡を抜いた後，プラスチック製閶筒 容器（直径 $3.7 \mathrm{~cm} \times$ 高さ $2 \mathrm{~cm}$ ) に充填し，キャップで密 封して $25^{\circ} \mathrm{C}$ で坐り在行った。（以上の操作で得たゲルを 以下坐りゲルと呼ぶう。また，比較のため $0.2 \mathrm{~N} \mathrm{HCl}$ を $\mathrm{pH} 6.0$ となるように添加して塩ずりし，同じ湿度で坐ら せる。

かまぼこのゲル物性の測定 坐りゲルにつき，レオ メーター(レオナーRE-3305, 山電(株)製)を使用して, 直径 $5 \mathrm{~mm}$ の円柱型プランジャーで破断強度 $(\mathrm{g})$ と破断 山み $(\mathrm{mm})$ を測定した。

塩ずりおよび坐り中の肉糊のタンパク質の塩溶解性の 測定 Fig. 1 に方法の概略を示すように，塩ずり肉抢よ び坐り中の肉糊の一部を $0.43 \mathrm{M}(2.5 \%)$ または $0.80 \mathrm{M}$ $(4.7 \%)$ の NaCl 溶液中でホモジナイズ $\quad(15,000 \mathrm{rpm} \times$ 90 s）し，ガラス製のハンドホモジナイザーで均質化し た後，遠心分離 $(11,000 \mathrm{~g} \times 30 \mathrm{~min})$ して集めた上清中の 量から塩に対するタンパク質の溶解性を調べた。また， 溶解したタンパク質と不溶性のタンパク質をさらに SDS-尿素混液中に溶解してそれぞれのサブュニット成 分組成の分布之变化を検討した。

SDS-尿素混液に対する塩ずり肉および坐り中の肉糊 のタンパク質の可溶化率の測定 程ずりおよび坐り中の 肉糊 $0.4 \mathrm{~g}$ を精秤し， $7.5 \mathrm{~m} /$ の 2\% SDS-8 $\mathrm{M}$ 尿素-2\% 2メルカプトエタノール $-20 \mathrm{~mm}$ Tris- $\mathrm{HCl}(\mathrm{pH} 8.0)$ 溶液 を加えて $100^{\circ} \mathrm{C}$ で 2 分間加熱した徭, 空温で 24 時間瀶 拌しながら可溶化させた。可溶化率は上記の溶液を $10,000 \times g$ で 20 分間遠心分離後, 供試したタンパク質量 に対する上清中のタンパク質量の相対值 (\%)で表した。 なお，タンバク質濃度の定量にはビウレット法゙を用い た。

SDS-PAGE による坐りゲル中の Mf タンパク質サブ ユニット成分の定量 Weber と Osborn の方法占により, 5\% ポリアクリルアミドゲルを用いた SDS-PAGEを行 い, Coomassie Brilliant Blue Rによって染色した。脱色 は $50 \%$ メタノール-7\% 酶酸で 6 8 時間, 続いて 7\% 酷酸でゲルの背景が透明化するまで行った。泳動ゲル上 の各 Mf タンパク質のサプュニット成分量は、デンシト メーター（(株)島律製作所製 CS-910 型）を用いて 640 $\mathrm{nm}$ と $700 \mathrm{~nm}$ の吸光値の差として測定し，泳動ゲル上に

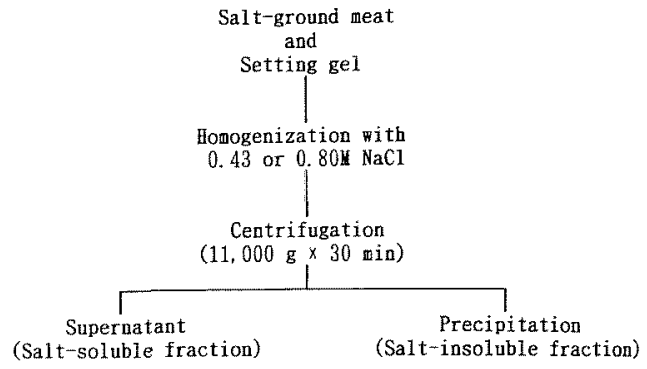

Fig. 1. Fractionation of myofibrillar proteins in salt-ground meat and setting gel with salt solution.

Surimi of walleye pollack, which contained sugar but no polyphosphate, was chopped with $2.5 \%(0.43 \mathrm{M}) \mathrm{NaCl}$ at a protein concentration of $130 \mathrm{mg} / \mathrm{g}$ wet weight of surimi in a speed cutter (National MK-K7) for $3-5 \min$ at $4^{\circ} \mathrm{C}$ or below. The $\mathrm{pH}$ of chopped meats was adjusted to 6.0 or 6.9 with or without the addition of a small amount of $\mathbf{H C l}$. The saltground meat was stuffed into a plastic vessel with a cover and incubated at $25^{\circ} \mathrm{C}$ to prepare "setting gel". After cooling in ice water, the gel $(5-10 \mathrm{~g})$ was homogenized with $15 \mathrm{~m} /$ of 0.43 or $0.80 \mathrm{M} \mathrm{NaCl}-20 \mathrm{~mm}$ Imidazol-HCl ( $\mathrm{pH}$ 7.0 ) at $15,000 \mathrm{rpm}$ in a mixer (Nihon Seiki) for $30 \mathrm{sec}$ and the homogenization was repeated 3 more times at intervals of $30 \mathrm{~s}$. After further mixing with the same $\mathrm{NaCl}(\mathrm{pH} \mathrm{7.0)}$ solution using a glass homogenizer, it was measured up to a definite volume of $50 \mathrm{ml}$ and centrifuged at $11,000 \times g$ for $30 \mathrm{~min}$ to separate the supernatant and precipitate fractions. The protein content was determined by the biuret method ${ }^{4}$.

認められる各成分の染色強度の合計値に対する相対染色 強度 (\%) として表した。定量した成分はミオシン $\mathrm{HC}$, その多量体，A，トロポミオシン $(\mathrm{TM}), \mathrm{X}_{1}$ ，および $\mathrm{X}_{2}$ （A 上り移動度の大きい成分）であるが, 各成分の説明は それぞれの寒駼結果の項に記載した。なお沼倉ら゙は， 泳動ゲル上の全染色强度の回収率が低下する場合がある ことを見いだしており，これは，SDS一尿素混液に可溶化 したミオシン HC 多量体の中であ，上り分子サイズの大 きい成分 (これを $\mathrm{HC}_{n}$ ，表す)が泳動ゲル中に侵入でき ないために起こったものと推測し，その量を計算によっ て求めた。さらに，坐りゲルがSDS-尿素混液に不溶化 する場合は，それらの成分をミオンン HC 多量体の特に 巨大化した成分（これを $\mathrm{HC}_{n^{\prime}}$ と表す）であると見なし て，各成分の含量を補正しているが，本実験においても 同様にその方法にならって補正した。 
(A)

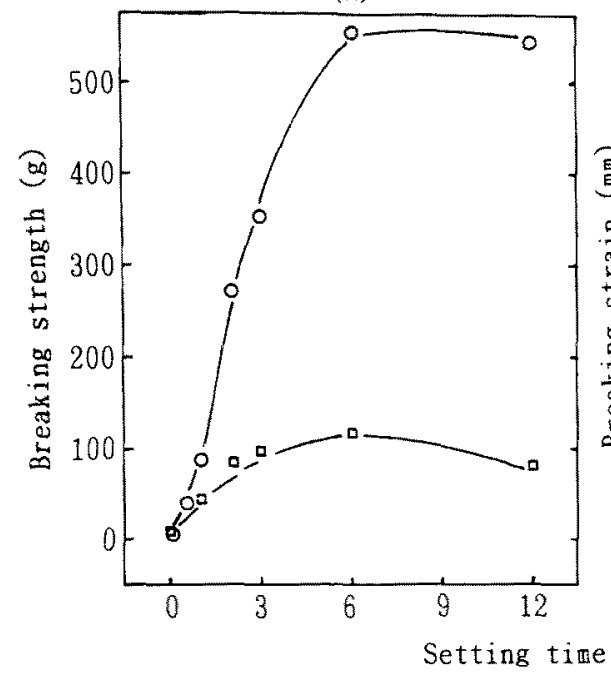

(B)

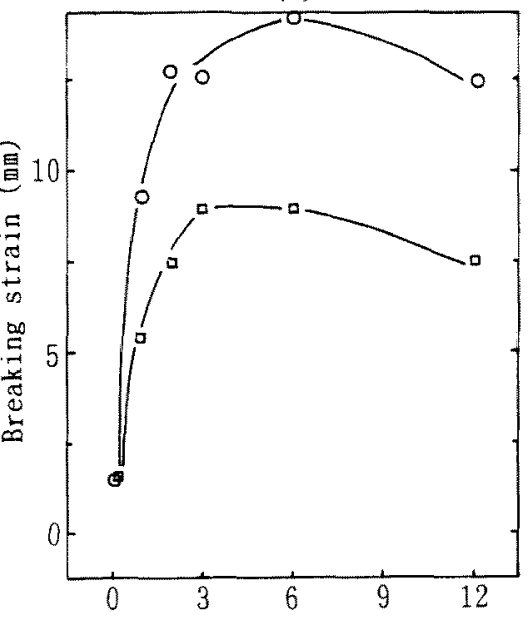

(h) at $25^{\circ} \mathrm{C}$

Fig. 2. Changes in breaking strength and breaking strain of salt-ground meat during setting.

The setting gel was prepared from the frozen surimi by mixing with $0.43 \mathrm{M} \mathrm{NaCl}$ as shown in Fig. 1. After cooling the gels with ice water, the load values of breaking strength ( $\mathrm{g}$ ) and breaking strain (mm) at the breaking point were evaluated at room temperature with a rheometer equipped with a $\phi 5 \mathrm{~mm}$ plunger.

(A): Breaking strength.

(B): Breaking strain.

The pHs for setting were $6.9(\mathrm{O})$ and $6.0(\square)$.

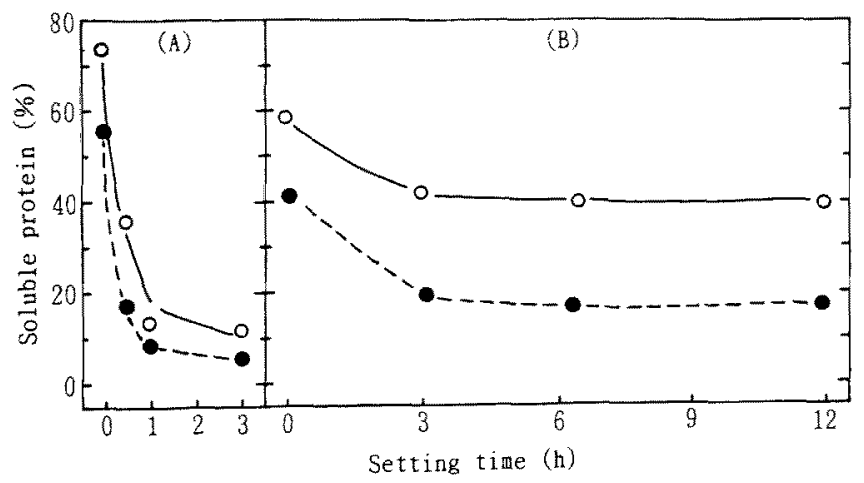

Fig. 3. Change in salt-solubility of myofibrillar proteins in salt-ground meat during setting.

The preparation of setting gel and the determination of salt-solubility of myofibrillar proteins in the gel were conducted as shown in Fig. 1. The protein concentrations were measured by the biuret method. ${ }^{4}$

Soluble protein $(\%)=(a / b) \times 100$

Where $a$ is the amount of supernatant protein $(\mathrm{mg})$ after centrifugation, and $b$ is the amount of total protein $(\mathrm{mg})$ before centrifugation.

Solid line : Soluble protein (\%) from the setting gel chopped with $0.80 \mathrm{M} \mathrm{NaCl}$.

Dotted line: Soluble protein (\%) from the setting gel chopped with $0.43 \mathrm{M} \mathrm{NaCl}$.

(A) $\mathrm{pH} 6.9$, (B) $\mathrm{pH} 6.0$.

\section{実稌䊅果}

塩ずりおよび坐り中の肉糊の破断強度と凹みの経眭変

化 $\mathrm{pH} 6.9$ と6.0に調節したすり身を塩ずりした後、 $25^{\circ} \mathrm{C}$ で肉糊を加温し，坐りゲルの破断強度と凹みの経時 変化を測定し，結果を Fig. 2(A) と(B)に示した。これ による之, pH 6.9 の坐りゲルの破断強度と凹みは共に坐

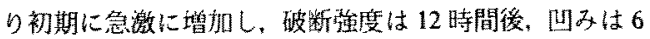


時間後にほぼ最大に達した。一方，pH 6.0 で塩ずりし， 坐らせたゲルの場合の破断強度之凹みは, pH 6.9 の場合 よりもかなり低く、3〜6時間後にほぼ最大に達した。

\section{塩ずりおよび坐り中の肉糊の Mf タンパク質の塩溶解}

性の変化 $25^{\circ} \mathrm{C}$ における坐りゲル中の $\mathrm{Mf}$ タンパク質 $の \mathrm{NaCl}$ 溶液に対する溶解性にっいて Fig. 3 に示した。 すなわち，上記の塩ずり肉および坐りゲルの一部を経時 的に取り出し，Fig. 1 のと㧍り，9倍量の0.43または $0.80 \mathrm{M} \mathrm{NaCl}-20 \mathrm{mM}$ Imidazol- $\mathrm{HCl}(\mathrm{pH} 7.0)$ 溶液を加元 てホモジナイズし，さらにハンドホモジナイザーで均質 化した後，直与に（15 分以内） $11,000 \times g$ で 30 分間遠心 分離して得た上清に溶解する夕ンパク質量 $(\mathrm{mg})$ を求 め，全供試タンパク質量 $(\mathrm{mg})$ に対する割合 $(\%)$ を塩溶 解性しして表した。これによると， $\mathrm{pH} 6.9$ の場合 (A) は， $\mathrm{NaCl}$ 濃度が $0.43 \mathrm{M}$ の時には塩ずり直後におけるそ の溶解性は $50 \%$ 以上之比較的高いが，その後に急激に 低下し，例元ば 1 時間後には 10\% 以下と低い值を示し た。また， NaCl 濃度が $0.80 \mathrm{M}$ になると塩ずり直後の深 解性は $0.43 \mathrm{M}$ の場合上りも高くなる $(73 \%)$ が, その後 に急激に低下する点は同じで，塩ずり1時間後で $14 \%$ となった。一方, pH 6.0 の場合 (B)は, $\mathrm{NaCl}$ 漛度が 0.43 M の時には塩ずり直後の溶解性が $42 \%$ であり，その値 は坐りの進行ととあにわずかに減少するすのの, 12 時間 㣪には $16 \%$ であった。また, $\mathrm{NaCl}$ 濃度が $0.80 \mathrm{M}$ になる 上塩ずり直後の溶解性が $58 \%$ に上昇し，同じ $\mathrm{NaCl}$ 濃 度の $\mathrm{pH} 6.9$ の場合上りは劣るが，比較的高い值を示し， またその值は坐りの進行之ともにわずかに滅少するもの の，12 時間後でも $40 \%$ の值在維持した。この上うに $0.80 \mathrm{M} \mathrm{NaCl}$ では比較的高い溶解性を示すので本研究で は $0.80 \mathrm{M} \mathrm{NaCl}$ 在採用した。

塩ずりおよひ坐り中の肉糊より塩で溶解するタンパク 質のサプユニット組成の経時变化 Fig. 3 に示した同じ 坐りゲルを $0.80 \mathrm{M} \mathrm{NaCl}$ 浴液でホもジナイズし，上清 (塩溶性画分) と沈殿（不溶性画分）に分けたが，この際 の遠心分離前の試料, 遠心後の上清, および沈殿中の Mf タンバク質の SDS-尿素混液に対する可容化率と組 成を測定した。その結果は图示しないか，pH6.9の場合 は，遠心分離前の武料上沈殿中の Mf タンパク質の可溶 化率は坐りに伴ってやや低下し，12 時間後には $96 \%$ と なった。上清中のその可浚化率はほ上んど 100\%を保っ た。一有，pH 6.0 の場合は，遠心分離前の試料と上清お よび沈殿の可溶化率はいずれすほぼ 100\%を保持した。 そこでまず，SDS一尿素混液に溶加した遠心分離前の試 料中の Mf タンパク質サブュニット組成を 5\% ポリアク リルアミドゲルを用いた SDS-PAGE 法で分析し, デン シトメトリーによって定最し，その結果を各サブュニッ ト成分ごとに Fig. 4(A) $(\mathrm{a} \sim$ d, m o ) と Fig. 5(A) $(\mathrm{a} \sim \mathrm{c}$, j〜1)に示した。なお，上清 (B) 上沈殿 (C) 中のタンパク 質の回収量を考慮し，遠心分離前の全供試タンパク質量 を基準として上清と沈殷画分中の Mf タンパク質サブュ ニット成分の定量値 (\%) を算出し, その結果を Fig. 4(B) $(\mathrm{e} \sim \mathrm{h}, \mathrm{p} \sim \mathrm{r})$ よ Fig. 5(B) (d f, m o) および Fig. $4(\mathrm{C})(\mathrm{i} \sim \mathrm{l}, \mathrm{s} \sim \mathrm{u})$ と Fig. $5(\mathrm{C})(\mathrm{g} \sim \mathrm{i}, \mathrm{p} \sim \mathrm{r})$ に示した。す な⿰ち，この結果は溶解成分之不溶成分中への各サブ ニット成分の分布を示している。こ㧈による上，まず $\mathrm{pH} 6.9$ の場合 (Fig. 4) は，遠心分離する前 (A) の試料中 には多量のミオシン $\mathrm{HC}(\mathrm{d})$ とそれにつぐ量の $\mathrm{A}+\mathrm{TM}$ (n) が含まれているが，坐り時間の進行とともにその中 のミオシン HC (d) が急激に減少し, それに伴い $\mathrm{HC}_{n}$ (c) が著しく增加し, 続いて $\mathrm{HC}^{\prime}$ (b) が增加し，ほ注同 時に $\mathbf{H C}_{n^{\prime \prime}}$ (a) がわずかながら增加してくることが示さ れた。なお，その他の成分の中では， $\mathrm{X}_{1}$ 成分 $(\mathrm{m})$ 加はん のわずかながら增加するが, $\mathrm{A}+\mathrm{TM}$ の成分 (n) と $\mathrm{X}_{2}$ 成 分 (o) はほ上んど変化しなかった。ついで (A)を遠心分 離して得た上清中の Mf タンパク質（程溶性タンパク 質）の場合 (B) は，坐りの進行之共に塩に対する溶解性 が急激に低下するため各成分の分析は 3 時間後までしか できなかった。坐り前の成分はミオシン HC (h) と A十 $\mathrm{TM}$ (q) であり，前者は分画前の $74 \% ，$ 後者は 77\%に相 当している。また，坐りに伴って同画分中のミオシン $H C(h)$ は急激に減少するか， $H_{n}(\mathrm{~g})$ は蓄嫧せずに減少 し, $\mathrm{HC}_{n^{\prime}}$ (f) は極めてわずかに増加するが， $\mathrm{HC}_{n^{n}}$ (e) は ほとんど增加しなかった。また， $\mathrm{X}_{1}$ 成分 $(\mathrm{p})$ も緩やかな 減少, $\mathrm{A}+\mathrm{TM}$ の成分 $(\mathrm{q})$ は急激な隇少, および $\mathrm{X}$ 成分 (r)の緩やかな隇少が見られた。この結果は, 塩ずり直 後の肉糊中には多量（約 70\%以上）のミオシン $\mathrm{HC}$ と $\mathrm{A}+\mathrm{TM}$ が未だ塩に溶解する状態で存在しているが，坐 りの進行に伴って急激に不溶化すること，また生成物は 塩溶性ではないため上清中からは一方的に消失していく ことを示している。さらに，(A) 在遠心分離して得た就 殿中のタンパク質 (C) を見ると, 塩ずり直後の肉糊の場 合にはごく少量（分画前の約 $11 \%$ と 8\%) のミオシン $\mathrm{HC}$ (l) と A+TM (t) が塩に溶解しにくい状態で存在し ているが，坐りの進行に伴って前者は減り，後者は大き く增加すること，また不溶性の成分中には多量の $\mathrm{HC}_{n}$ (k) とそれにつぐ量の $\mathrm{HC}_{n}$ ( (j) とごく少量の $\mathrm{HC}_{n}$ (i) の 他に, 多量の $\mathrm{A}+\mathrm{TM}(\mathrm{t})$ と少量の $\mathrm{X}_{1}$ 成分 (s) と $\mathrm{X}_{2}$ 成 分 (u) が蓄積していくことを示している。言い换え扎 ば, ミオシン HC 単量体 (1) を除く他のタンパク質成分, すなおち $\mathrm{HC}_{n^{\prime \prime}}$ (i), $\mathrm{HC}_{n} \cdot(\mathrm{j}), \mathrm{HC}_{n}(\mathrm{k}), \mathrm{X}_{1}$ 成分 (s), $\mathrm{A}+\mathrm{TM}$ (t), $\mathrm{X}_{2}$ 成分 (u) はいずれも上清汃ら沈殿中に移行する 傾向が見られる。ただし，この不溶性成分がどのような 組成の母体分子からなっているかはまだ断定できない。 またここには示さないが，ゲル濾過法によるとそれは極 

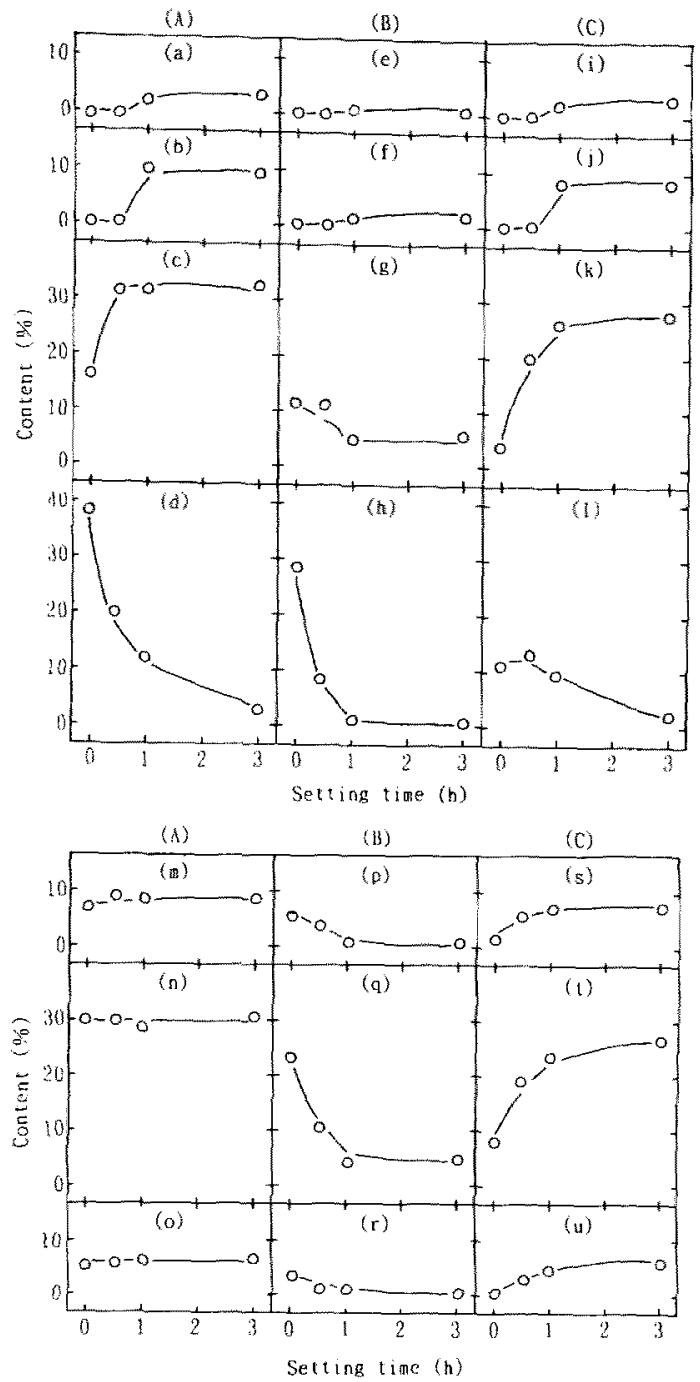

Fig. 4. Changes in subunit contents of myofibrillar proteins in salt-ground meat ( $\mathrm{pH}$ 6.9) during setting.

The preparation of setting gels $(\mathrm{pH} 6.9)$ and fractionation of soluble and insoluble proteins were conducted as shown in Fig. 1. The protein fractions were treated with $2 \%$ SDS $-8 \mathrm{M}$ urea-2\% mercaptoethanol-20 $\mathrm{mM}$ Tris- $\mathrm{HCl}(\mathrm{pH} 8.0)$ at $100^{\circ} \mathrm{C}$ for $2 \mathrm{~min}$, followed by stirring at room temperature for $24 \mathrm{~h}$. The identical aliquots (each $15 \mu \mathrm{g}$ protein) of the solubilized protein were applied to SDS-polyacrylamide gel electrophoresis using $5 \%$ polyacrylamide gels and stained by Coomassie Briliant Blue $R$. The protein on gel rod was determinated by measuring the difference of absorbances at 640 and $700 \mathrm{~nm}$ with a densitometer, and the content of each component was expressed as a relative value $(\%)$, taking the total amount of protein supplied as $100 \%$, by the method of Numakura et al. ${ }^{1,1}{ }^{1}$

The whole protein in the fraction before centrifugation (A), and the proteins in the supernatant (B) and the precipitate (C) after centrifugation, as shown in Fig. 1, were subjected to SDS-PAGE.

(a), (e), (i) : Cross-linked myosin heavy chain, insoluble in SDS-urea medium $\left(\mathrm{HC}_{n}\right)$.

(b), (f), (j): Cross-linked myosin heavy chain, too large to migrate into $5 \%$ polyacrylamide gel $\left(\mathrm{HC}_{n}\right)$.

(c), (g), (k): Cross-linked myosin heavy chain, migrating into $5 \%$ polyacrylamide gel $\left(\mathrm{HC}_{n}\right)$.

(d), (h), (l): Myosin heavy chain (HC).

(m), (p), (s) : Components migrating between $\mathrm{HC}$ and actin $\left(\mathrm{X}_{1}\right)$.

(n), (q), (t): Actin + tropomyosin $(A+T M)$.

(o), (r), (u): Components migrating faster than tropomyosin $\left(\mathrm{X}_{2}\right)$. 

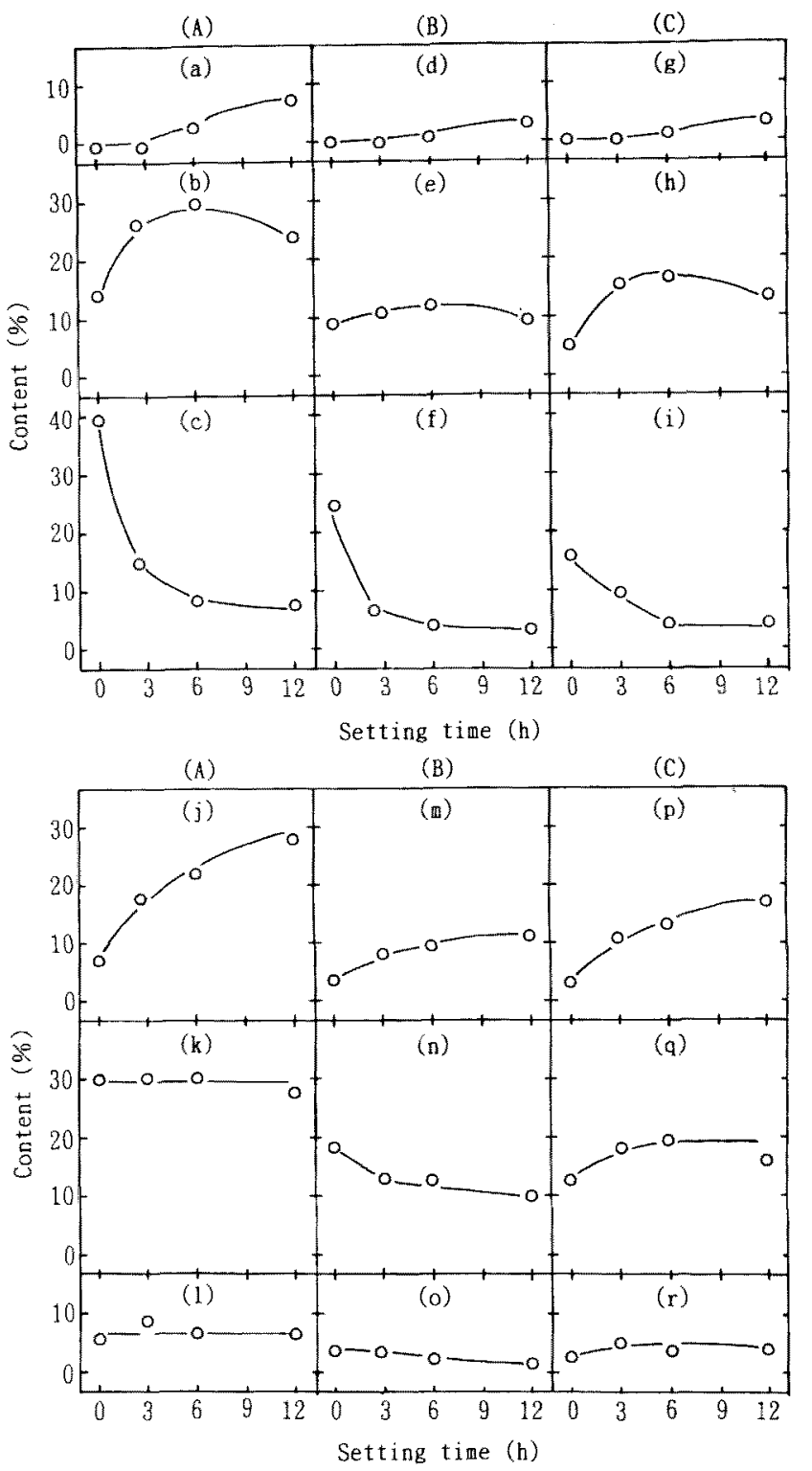

Fig. 5. Changes in subunit contents of myofibrillar proteins in salt-ground meat (pH 6.0) during setting.

The preparation of setting gels $(\mathrm{pH} 6.0)$ and the fractionation of supernatant and precipitate proteins were conducted as shown in Fig. 1. The SDS-PAGE of protein solubilized into SDS-urea medium was made as shown in Fig. 4. The quantitative determination of each subunit of myofibrillar protein was conducted as shown in Fig. 4.

The whole protein before centrifugation (A), and the proteins in the supernatant (B) and precipitate (C) after centrigugation were subjected to SDS-PAGE, as shown in Fig. 4.

(a), (d), (g): Cross-linked myosin heavy chain, too large to migrate into $5 \%$ polyacrylamide gel $\left(\mathrm{HC}_{n}\right)$.

(b), (e), (h): Cross-linked myosin heavy chain, migrating into $5 \%$ polyacrylamide gel $\left(\mathrm{HC}_{n}\right)$.

(c), (f), (i): Myosin heavy chain (HC).

$(j),(m),(p)$ : Components migrating between $\mathrm{HC}$ and actin $\left(X_{1}\right)$.

(k), (n), (q): Actin + tropomyosin (A + TM).

(l), (o), (r): Components migrating faster than tropomyosin $\left(\mathrm{X}_{2}\right)$. 
めて巨大な分子サイズのタンパク質複合体であることを 珰めた。杖

続いて pH 6.0 (Fig. 5) の場合は，上清と沈殿に分画す る前の試料中の組成 (A) を見ると，塩ずり直後の肉糊中 のサブュニット組成は pH 6.9 の場合に比べて余り変わ らなかった。しかし，坐りに伴うミォシン HC (c) の咸 少とその多量化应が全体に荤くなり, 結果として $\mathrm{HC}_{n}$ (a) の生成が抑制され，多量の $\mathrm{HC}_{n}$ (b) を蓄積するよう になり，またその他に多量のX，成分 (i) 在生成した。た

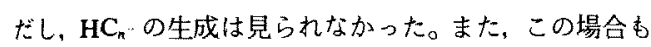
$\mathrm{A}+\mathrm{TM}(\mathbf{k})$ ，および $\mathrm{X}_{2}$ 成分 (1)には变化がなかった。つ いで，(A)を獭心分離して得た上清中の Mf タンパク質 の組成 $(B)$ を見ると，この場合も，督ずり直後の肉糊中 には，多量（それぞれ遠心分離前の約 60\%）のミオシン $\mathrm{HC}$ (f) と A+TM (n) が塩に溶解しゃすい状態で存在し ているが，坐りの進行に伴って急速に消失し，不溶性の 画分中に移っていくことを示している。な招 (m) と少量の $\mathrm{HC}_{n}$ (e)と $\mathrm{HC}_{n^{\prime}}$ 成分 (d) b塩に溶解する 状態で残されていた。だたし，程溶性タンバク質画分中 のミカシン HC (f) の減少は, pH 6.9 の場合に比べてや や遅く，かつその城少量は少ないが， $\mathbf{H C}_{n^{\prime}}$ (d) の生成量

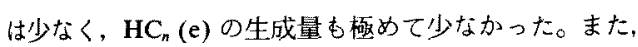
$\mathrm{A}+\mathrm{TM}(\mathrm{n})$ の量も減少したが， $\mathrm{X}_{1}$ 成分 $(\mathrm{m})$ の生成量は 比較的多く，分画前の約 $40 \%$ であった。しかし， X 2 成 分 (o) 9生成量は少なかった。さらに(A) を遠心分離し て得大沈殿中のタンパク質 (C) を見ると，この場合は塩 ずり直後の肉糊中にはすでに各約 $40 \%$ のミオシン HC (i) と A+TM (q) が溶解しにくい状態で存在している が, 坐りの進行に伴ってそれらの量が増加すること, ま たその中には比較的多量の $\mathrm{HC}_{n}(\mathrm{~h})$ と少量の $\mathrm{HC}_{n} \cdot(\mathrm{g})$, その他に比較的多量の A+TM (q) と $\mathrm{X}_{1}$ (p)（それぞれ の約 $67 \%, 60 \%$ に相当), さらに少量の $\mathrm{X}_{2}(\mathrm{r})$ が含まれ ていることを示している。また，盍ずり直後における上 清 (B) 中のタンパク質画分に比べてミオシン HC (i) の 量活約 8\% 程少ないが, $\mathrm{HC}_{n^{\prime}}(\mathrm{g})$ や $\mathrm{X}_{2}$ 成分 (r) 量はは ぼ同しで， $H_{n}(\mathrm{~h}), \mathrm{X}_{1}$ 成分 (p) の量, A+TM (q) の量 もやや少ないだけで，全体的にはその組成はよく似てい た。この結果は，pH 6.0 における坐りにおいて6 $\mathrm{pH} 6.9$ の湯合と同様にミオシンHCが減少してその多量体を

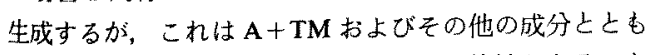
に複合して塩溶液中で不溶化していく可能性があること を示唆している。しかしここの複合タンパク質の組成は $\mathrm{X}_{1}$ 成分比較的多く含み, $\mathrm{pH} 6.9$ の場合と異なってい to

\section{若 察}

著者らはこれまで，肉糊のゲル化に及ばす各種の物理 化学的要因” (温度, 塩濃度, pH, タンパク質濃度) や添 加物（ソルビトール，グルタミン酸ナトリウム）の影 響8.9)につけて検討したが，同時に SDS-PAGE 法により 肉糊中の Mf タンパク質サブニニット組成の変化を解析 し，その結果から Mf タンパク質に起こる变化との関連 を考察してきた。しかし，この方法では肉糊中における Mf タンパク質がSDS一尿素混液中に溶解する前にどの ような構造体を形成していたかを知ることができない。 すなわち、よく知られているように, SDSや尿素はポリ ペプチド鎖内および鎖間に形成されている多数の非共有 結合を切断してしまうからである。そこで，本夷験では ゲル化しつつある肉糊中の Mf タンパク質の本体を調心

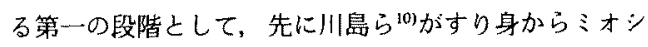
ンBを抽出する際に採用した高濃度 $(0.80 \mathrm{M}) の \mathrm{NaCl}$ 溶液を用いて肉糊をホモジナイズして溶解させこれ在 遠心分離して上清（塩溶性画分）上沈殿（不溶性画分） に分画し，塩に対する溶解性の変化を険討した。また同 時にをれぞれの画分中のタンパク質サブュニット組成存 屯調べた。その結果, $\mathrm{pH}$ が中性 (6.9) の肉糊の場合は, 塩ずり直後から坐りの開始 $\left(10^{\circ} \mathrm{C}\right.$ 前後で約 30 分間) ま では多垩のミオシン HCと A+TM成分の他に少量の $\mathrm{HC}_{n}, \mathrm{X}_{1}$ 成分， $\mathrm{X}_{2}$ 成分が溶解した。続いて，坐り $\left(25^{\circ} \mathrm{C}\right)$ が進行するにつれてミオシン HC が消失してその多量 体となるが，これはその他のあら功成分と共に不溶性 画分に含まれるようになった。一力，微酸性 (pH 6.0)の 肉糊の場合は，塩ずり後から坐り後の比較的長時間にわ たって高い壏溶解性を維持したが、これは肉糊の革いゲ ル化速度によく対応している。坐りに伴ってミオシン HC が消失し，その多量体が形成される点は同じである が， $\mathrm{X}_{1}$ 成尔が比較的多量に生成する点で中性の場合と 異なった。また， $x_{1}$ 成分の一部は可溶化したままで残る が，その大部分は他の成分亡とあに相互に弱い結合（非 共有結合 ${ }^{11}$ に上って疑集し，不溶化していく可能性が あることが示晙された。それゆえ，見かけ上は不溶性画 分中のミオシン $\mathrm{HC}$ 多量体對が減り， $\mathrm{X}_{\mathrm{I}}$ 成分の增量が 形成されるゲルの低い物性值に対杜している。

以上述べた結果は，肉糊の坐りに伴うゲル化において は, $\mathrm{pH} 6.9$ では大部分のミオシン $\mathrm{HC}$ 多舅体 $\left(\mathrm{HC}_{n}\right.$ ", $\mathrm{HC}_{n}$ ，拉よび $\mathrm{HC}_{n}$ ) の他に A+TM が，一方 $\mathrm{pH} 6.0$ の封 はその他に $X_{1}$ 成分が SDS-尿素混液中では切断してし まうような弱い結合力を介して巨大な複合体を形成し， 高濃度の塩溶液中で不溶化する可能性があることを強く

*6 平成 5 年度日本水産学会春季大会講演要旨集：スケトゥダラ肉糊の坐りに伴う塩溶性タンパク質の凝集体版成，1993，p. 282. 
示腹するあのである。なお，坐りの初期においてはミオ シン HCの一部は可溶化し，他の一部は不溶化してい る。さらに, pH 6.0 の坐りの後期においては $\mathrm{HC}_{n}, \mathrm{~A}+$ $T M ， お よ ひ ゙ X_{1}$ 成分が一部可溶化し，他の一部は不溶化 している。そ扎无，これらの成分の一部は複合体を形 成しておらずそのままの状態で存在し，また班成された

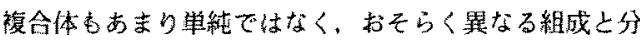
子サイズをもった湿合物である可能性も考磨しておく必 要がある。肉糊の塩ずりおよじ坐り中に形成される Mf タンパク質の複合体の分子サイズと組成については，す こにその一部を発表したが，煌その㲔細については次報 に变る。

\section{文献}

1) 沼會忠弘, 関 伸夫, 木村郁夫。剴田恭平, 藤田涍夫, 高 間浩藏，新井健一：坐りによる肉糊のゲル形成とミオシン の交差結合反店，日水蔆，51，1559-1565 (1985).

2）沼會忠弘。関 伸夫，木村郁夫、豊田恭平，藤田䓔夫，高 間浩感、新井煡一：坐りに伴うミオンン重銷の交差結合に 及ばす冷涷すりみの品筫の影響，日水誌，53，633-639 (1987).

3) 舩律保浩, 新井健一：スケトウダラ肉糊の坐りによるゲル 形成上ミオシン重銷の変化に及经す $\mathrm{pH}$ の影觜，日水誌。
57, 1973-1980 (1990)

4) A. G. Gornall, C. J. Bardawill, and M. M. David: Determination of serum proteins by means of the biuret reaction. $J$. Biol. Chem., 177, 753 -765 (1949).

5) K. Weber and M. Osborn: The reliability of molecular weight determination by dodecyl sulfatepolyacrylamide gel electrophoresis. J. Biol. Chem., 244, 4406-4412 (1962).

6）沼會忠弘，関 伸夫，木村郁夫，豐田㳟平，藤田莩夫，高 間浩蔵、新井健一：加熱により変質したスケトゥタラすり 身の坐りゲル形成能とミオンン重鎖の交差結合能、日水 誌, 55, 1083-1090 (1989).

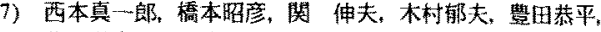
藤田孝夫, 新井健一: スケトウダラ肉糊の坐り中に起る: オンン䨘鎖とゲル強度の变化に影響する要因．日水誌 53, 2011-2020(1987)

8) 航律保浩，細川一，南部正一，新开健一：スケトウダラ 肉糊のゲル形成能とミオシン重鎖の多量化に及ぼすンル ヒトトルの影響。日水誌、59, 1599-1607 (1993).

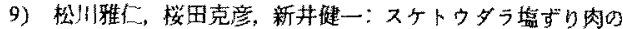
多翼化に及隹すピロリン酸塩の影響. 日水誌, 58, 735-742 (1992).

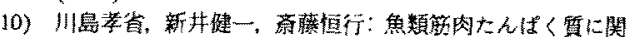
する研究一IX．スケトウダラ令涷すり身中のアクトミ才 シン定量条件の検討．日水誌，39，207-214 (1973)

11）柴田和雄：高次構造の化学的研究法，蛋白質の高次構造之 アミ八酸残基の状熊，学会出版センター，東京，1978, pp. 3-15. 